\title{
Aplikasi Sistem Informasi Manajemen pada Usaha Peternakan (Studi Kasus: Kelompok Tani Serambi Mekah Padang Panjang)
}

\author{
Application Management Information Systems (MIS) in dairy \\ cattle business (Case Study: Serambi Mekah farmer groups \\ Padang Panjang)
}

\section{Siska Fitrianti}

Staf pengajar Prodi Agribisnis Pertanian Politeknik Pertanian Negeri Payakumbuh

\begin{abstract}
Science and technology for society have been made in Serambi Mekah farmer groups with the aim to improving the managerial capacity of the business with the help of Management Information Systems (MIS). Event starts from the identification of the Standard Operational Procedure, making the algorithm, design tables, forms, queries and reports using Microsoft Access and Microsoft Visual Basic to a SIM application software. The results showed activities SIM can be used as a controller to support the business as a business decision and record all activities in a systematic and integrated transactions. SIM can provide information to support management decisions to be taken manager, enabling better decisions can be made quickly and accurately. Support bookkeeping in SIM allows manager can easily keep an eye on corporate wealth, monitor progress and provide reports to business stakeholders.
\end{abstract}

Key words : information systems, management, dairy cattle, bookkeeping

Diterima 19-03 2014, disetujui: 27-06-2014

\section{PENDAHULUAN}

Kota Padang Panjang merupakan daerah sentra peternakan sapi perah di Sumatera Barat dengan populasi sapi perah mencapai 1.602 ekor (BPS, 2010). Usaha peternakan sapi perah di daerah ini pada umumnya masih bersifat usaha keluarga dengan manajerial sederhana dari modal keluarga dan sebagian telah memanfaatkan sumber permodalan dari bank. Usaha peternakan sapi perah merupakan usaha padat modal dengan melibatkan banyak komponen sub sistem mulai dari pengadaan bahan baku, proses produksi, penjualan produk dan tenaga kerja sehingga perlu dikelola dengan menajemen yang baik.

Permasalahan umum dalam kegiatan bisnis sapi perah di daerah ini adalah masih lemahnya kegiatan pembukuan dan pengelolaan sumberdaya informasi. Pembukuan hanya dilakukan secara sederhana oleh peternak dengan mencatat pembelian sarana produksi, penjualan susu, pembayaran gaji, catatan hutang dan piutang, namun tidak diiringi dengan analisis hingga menjadi informasi yang berguna untuk mendukung keputusan manajer/pengusaha. Informasi merupakan salah satu sumber daya penting dalam manajemen moderen, banyak keputusan strategis yang bergantung 
kepada informasi. Sumber daya informasi merupakan salah satu bagian dari 4M+1I yang mencakup manusia, material, mesin dan modal serta informasi merupakan sumber daya vital bagi kelangsungan organisasi bisnis (Alter 2009).

Akibatnya manajer/pengusaha tidak mampu mengendalikan bisnisnya secara baik, efisien dan efektif. Pengusaha tidak mampu memantau perkembangan asetnya dari waktu ke waktu yang selalu dituntut oleh pihak bank dalam mendapatkan kredit. Pengusaha tidak tahu berapa jumlah keuntungan yang diperoleh setiap periode dan keputusan apa yang dapat diambil untuk meminimumkan biaya maupun memaksimumkan pendapatan.

Demikian juga dengan aktivitas harian, manajemen stock tidak bisa dilakukan dengan baik karena tidak tersedia informasi jumlah persediaan bahan baku dan berapa yang harus diorder kembali, berapa persediaan susu dan berapa pesanan yang mesti dipenuhi. Informasi yang lebih detil dan sangat dibutuhkan oleh pengusaha adalah berapa harga pokok produksi susu untuk penentuan harga jual susu. Keputusan manajemen stock, penetapan harga jual dan lain-lain selalu dilakukan oleh pengusaha dengan dasar pengalamannya tanpa dukungan data dan informasi.

Pengembangan SIM bermitra dengan usaha peternakan sapi perah Serambi Mekah. Usaha mitra tergolong usaha menengah dengan populasi sapi 50 ekor. Penggunaan SIM dalam kegiatan usaha ini diharapkan dapat meningkatkan produktivitas usaha. Kegiatan pembukuan akan lebih mudah, cepat dan akurat, pengendalian aset akan lebih efektif, akuntansi yang selama ini selalu menjadi masalah akan banyak terbantu dengan penggunaan SIM, semuanya itu akan menunjang pengambilan keputusan yang tepat bagi manajer.

\section{METODE}

Penggunaan sistem informasi manajemen (SIM) dalam usaha peternakan sapi perah Serambi Mekah mempunyai urgensi yang sangat tinggi dalam upaya meningkatkan produktivitas usaha bisnis. Usaha meliputi berbagai aktivitas sebagai suatu rangkaian sistem yang terdiri dari (1) subsistem pengadaan sarana produksi yaitu pakan, obat-obatan dan tenaga kerja (2) subsistem produksi berupa usaha peternakan sapi perah (3) subsistem penanganan hasil yaitu penanganan susu selesai pemerahan hingga diolah menjadi berbagai produk olahan susu, serta (4) subsistem distribusi dan pemasaran hasil.

SIM dapat menyediakan berbagai informasi bagi manajer sebagai pertimbangan dalam pengambilan keputusan seperti jumlah pembelian sarana produksi, volume penggunaan sarana produksi, jadwal pemberian vaksin, tingkat produksi susu, analisis feed convertion, jumlah penjualan susu, jumlah hutang dan piutang, analisis harga pokok produksi, analisis rugi laba dan berbagai informasi lainnya yang diperlukan manajer.

Software Sistem Informasi Manajemen (SIM) dibuat dengan menggunakan Microsoft Acces dan Microsoft Visual Basic. Kegiatan dimulai dari identifikasi Standard Operating Procedure (SOP) perusahaan dan kemudian dilanjutkan dengan penyusunan algoritma, pembuatan table, relationship antar table, perancangan user interface dan diakhiri dengan perancangan berbagai model pengolahan data menjadi informasi yang sesuai dengan kebutuhan manajer. 


\section{HASIL DAN PEMBAHASAN}

\section{Sistem Informasi Manajemen sebagai Sarana Pengendali Kegiatan/Proses Bisnis}

Penggunaan Sistem Informasi Manajemen (SIM) dalam usaha peternakan sapi perah dapat menjadi sarana pengendali kegiatan bisnis. Tampilan menu SIM seperti Gambar 1 dan kegiatan yang dapat dibuatkan pembukuannya meliputi :

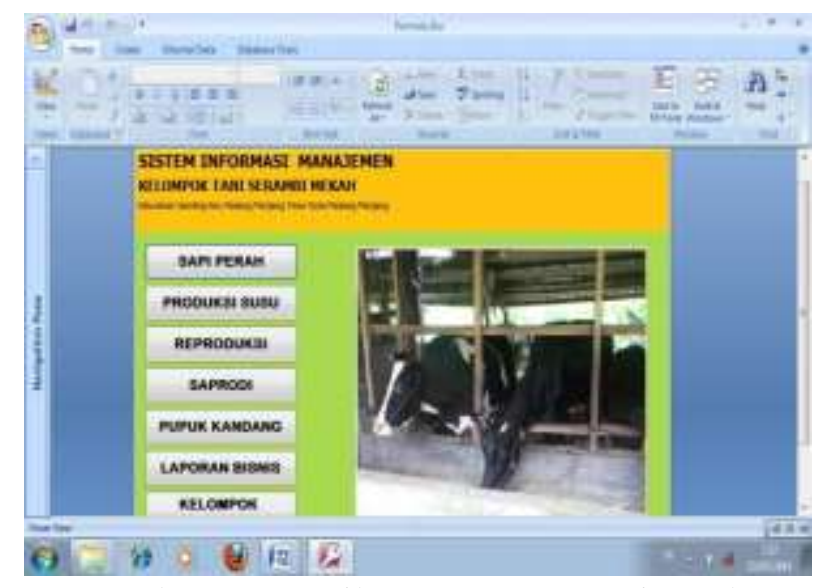

Gambar 1. Tampilan menu SIM Sapi Perah

\section{Data Sapi Perah/Recording Sapi Perah}

Pada fitur sapi perah dapat berfungsi sebagai Sistem Informasi Recording sapi perah yang ada pada kelompok tani dengan tampilan seperti pada Gambar 2 dan gambar 3.

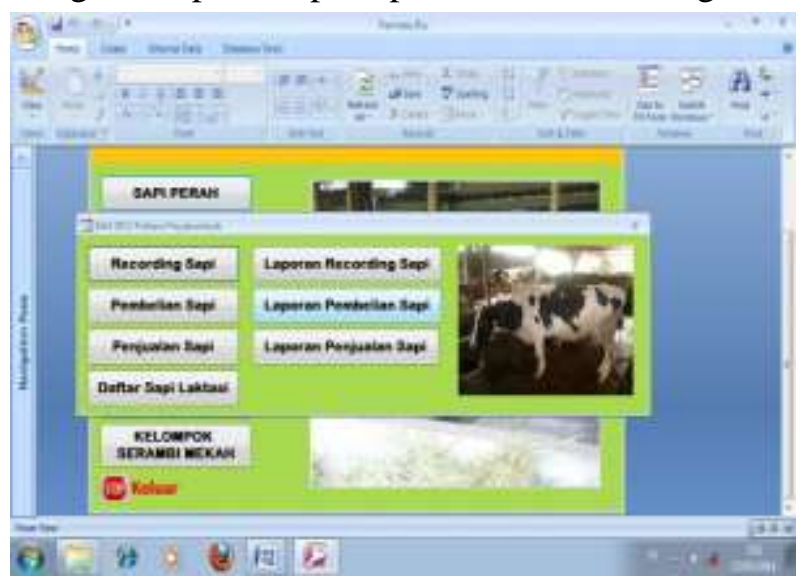

Gambar 2. Fitur Sapi Perah yang mencakup fitur recording sapi, pembelian sapi, penjualan sapi dan daftar sapi laktasi.

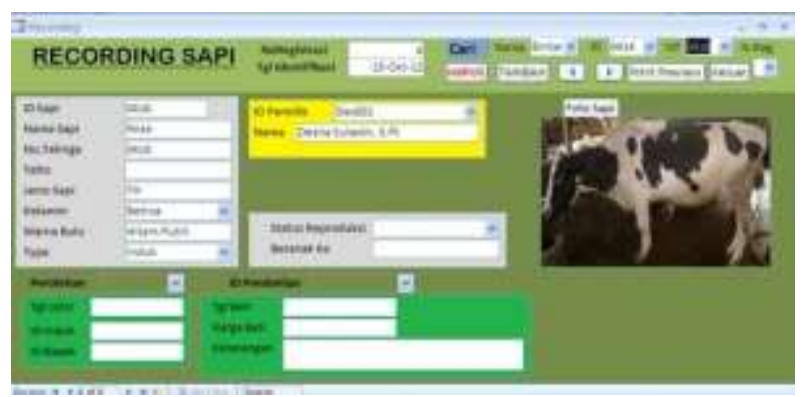

Gambar 3. Catatan dan Informasi Recording Sapi 
Pada fitur diatas, dapat dicatat nomor sapi, nama sapi, nomor telinga dan lain-lain yang memudahkan manajer/pengusaha mengidentifikasi jika terjadi permasalahan pada sapi (misalnya sapi sakit dst). Disamping itu pada fitur ini juga berguna sebagai Sistem Informasi untuk: pembelian sapi perah, penjualan sapi perah, dan daftar sapi laktasi.

\section{Data Produksi Susu}

Pada fitur ini mencatat dan menyediakan informasi tentang : catatan produksi susu anggota kelompok, catatan pembelian susu kepada mitra, dan catatan penjualan susu.

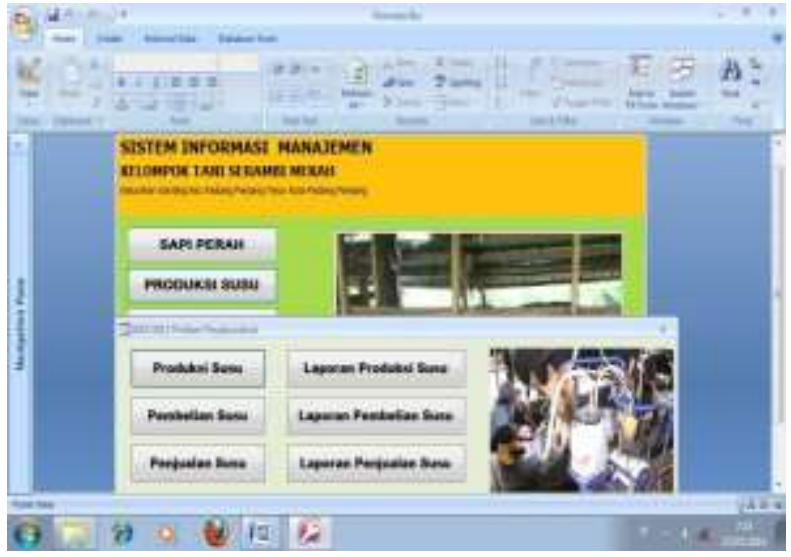

Gambar 4.Fitur Produksi Susu yang mencakup Produksi susu, pembelian susu dan penjualan susu.

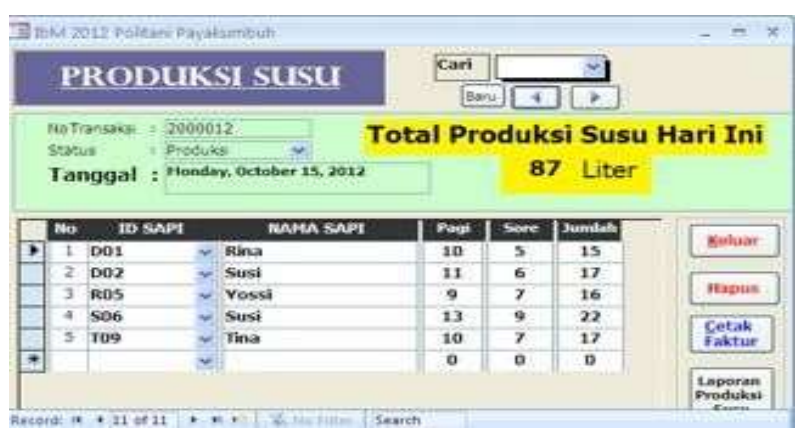

Gambar 5. Catatan dan Informasi Produksi Susu Sapi Perah

\section{Data Reproduksi}

Pada fitur reproduksi akan mencatat dan menyediakan informasi mengenai segala hal yang berkaitan dengan reproduksi sapi perah seperti pada Gambar 6 .

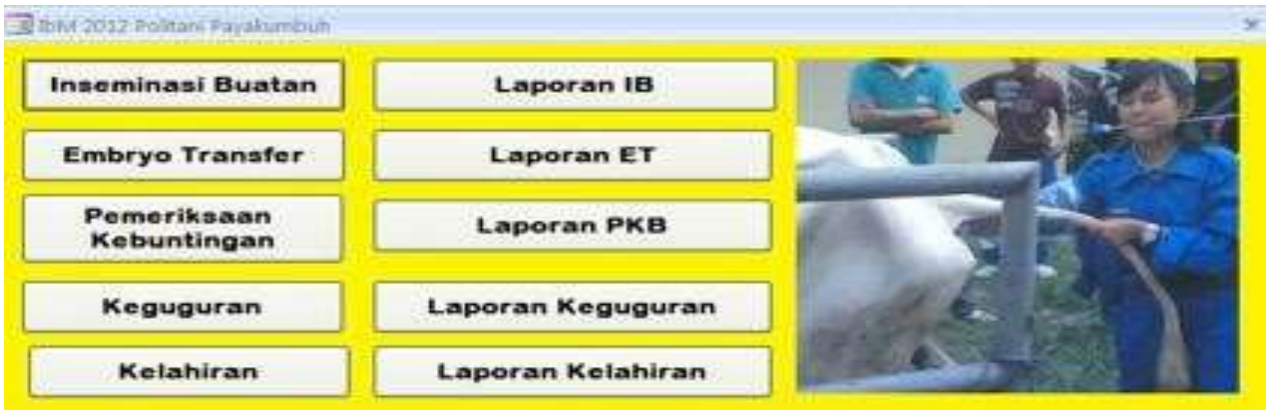

Gambar 6. Fasilitas atau sub-fitur yang tersedia pada fitur reproduksi 
Salah satu fitur yang sangat berguna dalam aktivitas reproduksi adalah Inseminasi Buatan (IB) dengan menyediakan informasi seperti pada Gambar 7.

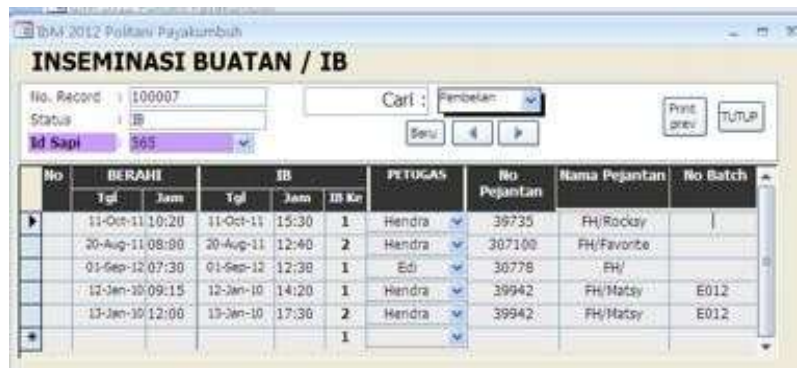

Gambar 7. Fitur untuk mencatat dan menyediakan informasi IB

\section{Transaksi pembelian bahan baku}

SIM akan menyediakan informasi stock bahan baku yang ada digudang, bahan baku apa saja yang harus diorder kembali dan berapa jumlahnya, siapa pemasok bahan baku tersebut dan informasi-informasi pendukung lainnya. Pada waktu terjadinya transaksi, SIM akan menyediakan Form (Gambar 8) yang dilengkapi dengan faktur dan laporan pembelian serta tercatat secara otomatis dalam pengeluaran kas.

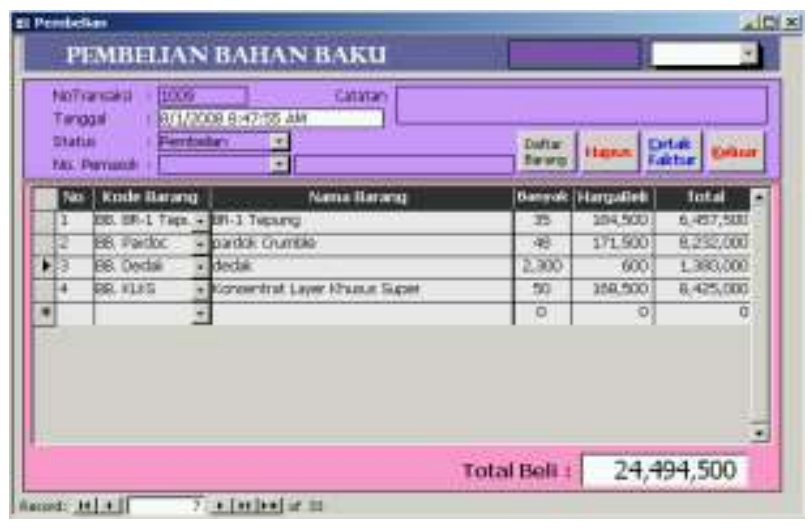

Gambar 8. Form Transaksi Pembelian Bahan Baku

\section{Penggunaan bahan baku}

Catatan penggunaan bahan baku menunjukan jumlah bahan pakan, obat, vitamin dan bahan lainnya yang diberikan kepada sapi. Untuk keperluan ini SIM menyediakan satu form (Gambar 9) yang dapat menampung data penggunaan bahan baku. Pada saat pencatatan, data yang dimasukan secara otomatis akan mengurangi stock, menambah konsumsi kumulatif ransum dan obat-obatan pada masing-masing flock kandang.

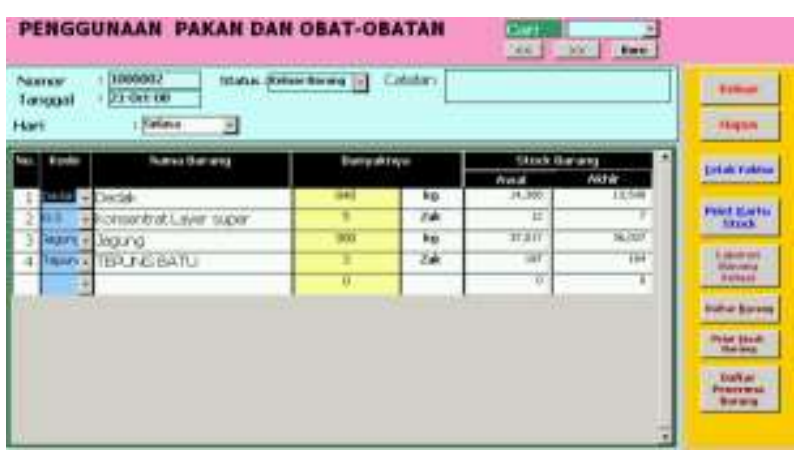

Gambar 9. Form Penggunaan Pakan dan Obat-obatan 


\section{Transaksi penjualan susu}

SIM menyediakan informasi stock susu yang tersedia di gudang sebagai acuan untuk manajer untuk melakukan transaksi penjualan. Pada saat transaksi SIM menyediakan Form Transaksi (Gambar 10) dan dilengkapi dengan faktur penjualan dan laporan penjualan serta tercatat secara otomatis pada penerimaan kas.

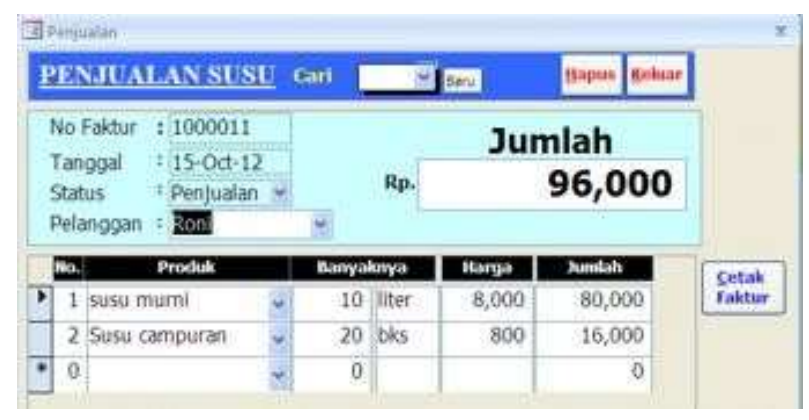

Gambar 10. Form Transaksi Penjualan Susu

\section{Pembayaran Gaji Karyawan}

Sistem penggajian di Serambi Mekah yaitu karyawan dibayar berdasarkan jumlah sapi yang ditanganinya, untuk itu SIM dapat menyediakan informasi populasi sapi yang ditangani setiap karyawan dan berapa gaji yang mesti dibayarkan kepada setiap karyawan. SIM menyediakan form Pembayaran Gaji lengkap dengan slip gaji dan laporan pembayaran gaji serta tercatat otomatis pada pengeluaran kas (Gambar 11).

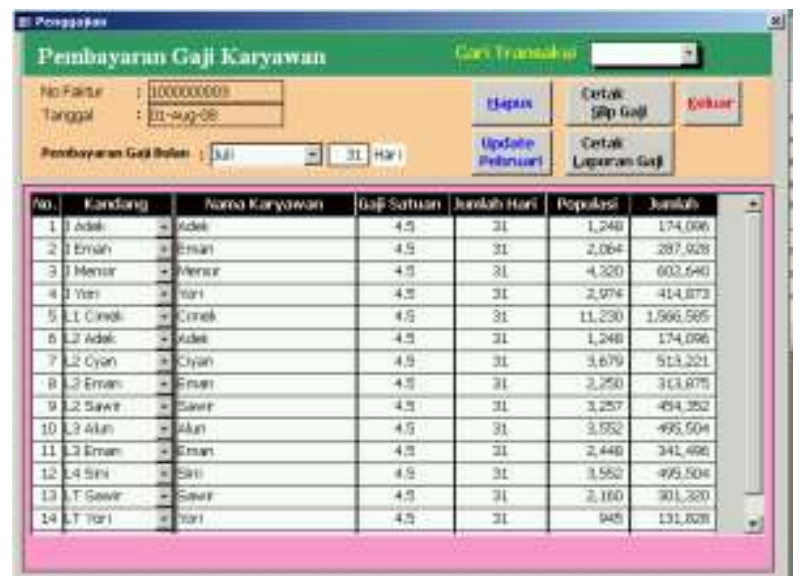

Gambar 11. Form Pembayaran Gaji Karyawan

Peranan SIM sebagai pengendali bisnis dalam usaha peternakan sapi Serambi Mekah memberikan dampak positif terhadap jalannya usaha antara lain :

1. Seluruh transaksi tercatat secara sistematis dan terintegrasi

2. Mengurangi beban manajer dalam pengendalian usaha yang dapat digantikan dengan program komputer.

3. Mengurangi human error dalam transaksi bisnis 


\section{Sistem Informasi Manajemen sebagai Penunjang Proses Pengambilan Keputusan}

Sistem Informasi Manajemen (SIM) yang diterapkan mampu mengolah data dari berbagai sub sistem yang ada di usaha menjadi berbagai informasi yang dibutuhkan oleh manajer sebagai penunjang pengambilan keputusan. Berbagai informasi tersebut terangkum pada Tabel 1.

Tabel 1. Jenis Informasi sebagai Penunjang Pengambilan Keputusan

\begin{tabular}{|c|c|c|}
\hline $\begin{array}{c}\text { Item } \\
\text { Informasi }\end{array}$ & Jenis Informasi & Jenis Keputusan \\
\hline \multirow[t]{2}{*}{ Sapi } & Populasi sapi & $\begin{array}{l}\text { 1. Populasi sapi laktasi yang produktif } \\
\text { 2. Populasi sapi dara dan pedet yang akan dijadikan } \\
\text { pengganti induk dan yang akan dijual } \\
\text { 3. Pengaturan komposisi populasi sapi laktasi, dara dan pedet }\end{array}$ \\
\hline & $\begin{array}{l}\text { Laporan morbiditas dan } \\
\text { mortalitas }\end{array}$ & $\begin{array}{l}\text { 4. Penanganan wabah penyakit } \\
\text { 5. Pencegahan penyakit dengan vaksinasi, pemberian feed } \\
\text { aditive antibiotika, dan sanitasi kandang. }\end{array}$ \\
\hline \multirow[t]{3}{*}{$\begin{array}{l}\text { Pakan dan } \\
\text { obat-obatan }\end{array}$} & $\begin{array}{l}\text { Laporan pembelian } \\
\text { bahan baku pakan dan } \\
\text { obat-obatan }\end{array}$ & $\begin{array}{l}\text { 6. Perhitungan jumlah pengeluaran } \\
\text { 7. Pemilihan supplier dengan penawaran harga terendah }\end{array}$ \\
\hline & $\begin{array}{l}\text { Stock bahan baku pakan } \\
\text { dan obat-obatan }\end{array}$ & $\begin{array}{l}\text { 8. Pemesanan bahan baku pakan dan obat-obatan } \\
\text { 9. Perhitungan nilai stock }\end{array}$ \\
\hline & Produksi Susu & $\begin{array}{l}\text { 10. Perbaikan kualitas pakan } \\
\text { 11. Sapi sudah tua dan harus diafkir } \\
\text { 12. Inspeksi cekaman penyebab stress } \\
\text { 13. Inspeksi datangnya wabah penyakit }\end{array}$ \\
\hline \multirow{2}{*}{ Susu } & Stock Susu & $\begin{array}{l}\text { 14. Volume penawaran susu kepada pelanggan } \\
\text { 15. Perhitungan nilai stock }\end{array}$ \\
\hline & Laporan Penjualan Susu & $\begin{array}{l}\text { 16. Perhitungan jumlah pemasukan usaha } \\
\text { 17. Pembandingan pemasukan antar periode }\end{array}$ \\
\hline
\end{tabular}

Pada Tabel 1 dapat dilihat bahwa informasi sangat dibutuhkan oleh manajer untuk menentukan keputusan manajemen yang tepat dan efektif. Informasi tingkat produksi susu yang rendah perlu dengan cepat ditangani agar tidak merugikan usaha, laporan stock susu menjadi acuan volume transaksi penjualan susu kepada pelanggan, catatan morbiditas dan mortalitas menjadi informasi adanya wabah penyakit dan perlunya penanganan dan pencegahan penyakit. Semua informasi ini dapat tersedia dengan cepat dan mudah dengan dukungan Sistem Informasi Manajemen.

\section{Sistem Informasi Manajemen sebagai Sarana Pembukuan/Pengolahan Transaksi Usaha}

Dukungan SIM dalam kegiatan bisnis usaha peternakan sapi perah Serambi Mekah telah membuka wahana baru dalam sistem pembukuan usaha dari pembukuan manual menjadi pembukuan elektronik yang terintegrasi seperti ditampilkan pada gambar 12 dan tabel 2. Laporan Aliran Kas akan memudahkan manajer untuk mengetahui jumlah pengeluaran kas/kas keluar, jumlah penerimaan kas/kas masuk serta saldo kas yang tersedia. Transaksi pengeluaran kas dapat terjadi karena adanya pembelian bahan baku, pembelian susu kepada mitra, pembayaran gaji dan lain-lain.Transaksi penerimaan kas dapat berasal dari penjualan susu, penjualan sapi maupun penerimaan piutang. Informasi mengenai laba atau rugi yang diperoleh dapat pula diketahui melalui Laporan Laba Rugi yang dihasilkan oleh SIM. Disamping itu beberapa analisa keuangan juga dapat diketahui melalui informasi yang terdapat dalam laporan laba rugi seperti R/C ratio, 
profit margin dan sebagainya. Sedangkan kondisi aset/kekayaan perusahaan, jumlah hutang, piutang dan modal usaha dapat dengan mudah diketahui melalui neraca.

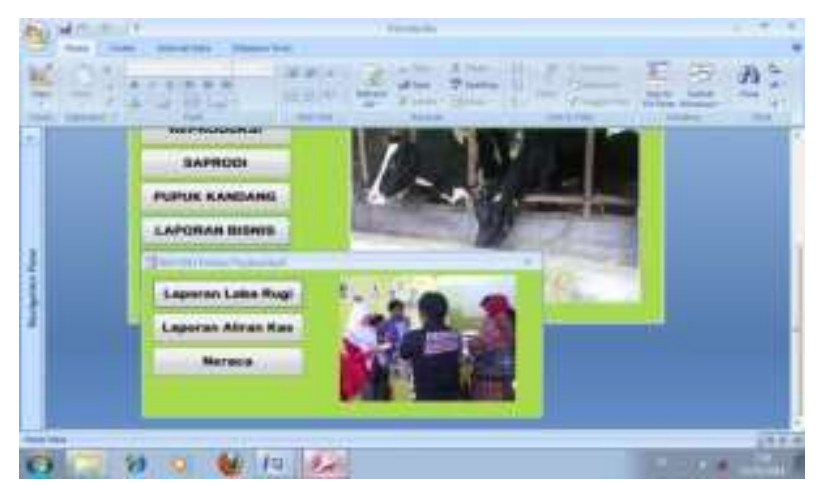

Gambar 12. Laporan hasil olahan SIM yang terdiri dari Laporan Laba Rugi, Laporan Aliran Kas dan Neraca.

Tabel 2. Pengolahan Transaksi Usaha berbasis Sistem Informasi Manajemen

\begin{tabular}{|c|c|c|}
\hline No & Jenis Laporan & Keterangan \\
\hline 1 & Laporan Arus Kas & $\begin{array}{l}\text { - Memberikan informasi tentang jumlah kas masuk dan kas keluar dari } \\
\text { operasional usaha dan saldo kas akhir pada waktu tertentu. }\end{array}$ \\
\hline 2 & Laporan Laba Rugi & $\begin{array}{l}\text { - Menampilkan laba rugi usaha dalam jangka waktu yang dapat ditentukan } \\
\text { sesuai kebutuhan, tahunan, bulanan, mingguan atau dari tanggal tertentu } \\
\text { sampai tanggal tertentu. } \\
\text { - Menganalisis biaya dan pemasukan dengan } \mathrm{R} / \mathrm{C} \text { ratio }\end{array}$ \\
\hline 3 & Neraca & $\begin{array}{l}\text { - Menampilkan kondisi aktiva (piutang dan aset lainnya) dan pasiva } \\
\text { perusahaan pada waktu tertentu. } \\
\text { - } \\
\text { Periode waktu dapat ditentukan berdasarkan bulan dan tahun sesuai } \\
\text { kebutuhan manajer. }\end{array}$ \\
\hline
\end{tabular}

Penerapan SIM dalam usaha peternakan sapi perah Serambi Mekah di bidang pembukuan sangat berperan penting sebagai pengaman harta kekayaan perusahaan dan sebagai penunjang proses pengambilan keputusan. Dengan adanya unsur-unsur pengendalian atau pengecekan dalam sistem akuntansi, berbagai kecenderungan, penyimpangan dan kesalahan dapat dihindarkan atau dilacak sehingga dapat diperbaiki.

Pengolahan transaksi usaha yang selama ini menjadi permasalahan utama perusahaan karena keterbatasan kemampuan pengusaha dan karyawannya, dapat terpecahkan dengan menggunakan SIM. Pembukuan dengan SIM dapat dilakukan sendiri oleh perusahaan tanpa membutuhkan keahlian akuntansi dan dapat menyediakan informasi accounting yang cepat dan akurat.

SIM mampu mengolah data dan menyediakan informasi mengenai kondisi usaha yang sangat dibutuhkan oleh manajer. Berbagai informasi tersebut meliputi :

- Jumlah pendapatan dan biaya yang dihasilkan dalam suatu periode tertentu

- Posisi keuangan perusahaan, yang meliputi aktiva, kewajiban dan ekuitas pada suatu saat tertentu

- Berbagai informasi manajerial lain yang terinci sebagai pendukung informasi mengenai pendapatan, biaya, aktiva, kewajiban dan ekuitas seperti informasi mengenai penjualan, piutang, pembelian, utang dan lainnya. 
- Informasi lain yang harus disajikan kepada stakeholder atau berbagai pihak berkepentingan dengan perusahaan, seperti instansi pajak, bank dan kreditur.

\section{KESIMPULAN}

Penerapan Sistem Informasi Manajemen (SIM) dalam usaha peternakan sapi perah Serambi Mekah memberikan pengaruh positif dalam perbaikan manajemen usaha meliputi :

a. SIM dapat digunakan sebagai pengendali bisnis karena dapat menunjang keputusan bisnis dan mencatat seluruh kegiatan transaksi secara sistematis dan terintegrasi.

b. SIM dapat menyediakan informasi untuk menunjang proses pengambilan keputusan yang akan diambil manajer, memungkinkan keputusan dapat diambil lebih cepat dan tepat.

c. Pengolahan transaksi dalam SIM memungkinkan manajer dapat dengan mudah mengawasi kekayaan perusahaan, memantau perkembangan usaha dan memberikan laporan kepada stakeholders.

\section{DAFTAR PUSTAKA}

Alter, S. 2009. Information Systems : A Management Perspective. The Benjamin/Cummings Company, Inc.

BPS. 2010. Sumatera Barat dalam Angka. Badan Pusat Statistik Sumatera Barat. Padang.

O’Brien, J.A. 1996. Management Information Systems : Managing Information Technology in the Networked Enterprise. 3th Ed. Times Mirror Higher Education Group.

Kadir, A. 2003. Pengenalan Sistem Informasi. Penerbit Andi Yogyakarta.

Ramaiyulis, 2006. Teknik Desain Database. Buku Penuntun Praktikum Aplikasi Komputer Bisnis. Politeknik Pertanian Negeri Payakumbuh.

Widjajanto, N. 2001. Sistem Informasi Akuntansi. Penerbit Erlangga Jakarta. 